\title{
A failure to communicate: the fact-value divide and the Putnam-Dasgupta debate
}

\author{
HUEI-CHUN SU \\ University College London \\ DAVID COLANDER \\ Middlebury College
}

\begin{abstract}
This paper considers the debate between economists and philosophers about the role of values in economic analysis by examining the recent debate between Hilary Putnam and Sir Partha Dasgupta. It argues that although there has been a failure to communicate there is much more agreement than it seems. If Dasgupta's work is seen as part of the methodological tradition expounded by John Stuart Mill and John Neville Keynes, economists and philosophers will have a better basis for understanding each other. Unlike the logical-positivist tradition, which treats facts and values as two mutually exclusive concepts, the MillKeynes tradition recognizes that facts and values are intertwined. Unlike the Smithian tradition, which blends the study of facts and normative rules, it divides economics into a science that studies "what is" and an art which considers "what ought to be done".
\end{abstract}

Keywords: methodology, logical positivism, values, positive, normative

JEL Classification: A13, B20, B41

In thinking about the on-going debate between philosophers and economists about the place of values in economics, one cannot help but be reminded of that famous line in the movie Cool Hand Luke, "What we've got here is a failure to communicate". Despite attempts to resolve the debate, there seems to be little agreement, with many economists continuing to believe that economics should study and indeed does study facts, not values; many philosophers continuing to

AUTHOR's NoTE: We would like to thank Partha Dasgupta for helpful comments on an earlier version of this paper. We would also like to thank the anonymous referees and especially the editor Thomas Wells for his careful editing and many suggestions for improvement, many of which we followed. We remain responsible for any errors. 
believe that economists are hopelessly confused; and neither side recognizing the other's position as defensible.

A recent flare up of this debate can be seen in the on-going exchange between Hilary Putnam-writing together with Vivian Walsh (2007a; 2007b; 2009; 2012) -and Sir Partha Dasgupta (2005; 2007a; 2009), both representative of the best in their field. The debate between them began in an unusual manner. In his book An inquiry into well-being and destitution (1993, 6-7), Dasgupta cited Putnam (1981; 1989) to the effect that an entanglement of facts and values is unavoidable and that that entanglement would influence the way he argued. Based on that citation, and a reading of Dasgupta's work, Putnam saw Dasgupta as an example of how economists can do economic policy analysis right-i.e., by explicitly including ethical judgements in their work.

If Putnam believed that he and Dasgupta were in the same camp, that belief was shattered when, in a 2005 article 'What do economists analyze and why: values or facts?' published in the journal Economics and Philosophy, Dasgupta took issue with claims that Putnam had made about how he was including values in his economic analysis. Dasgupta argued that what economists do is analyze facts, and that in professional debates on social policy economists differ primarily on their reading of the facts, not on their values. He further claimed that "Ethics has taken a back seat in modern economics not because contemporary economists are wedded to a 'value-free' enterprise, but because the ethical foundations of the subject were constructed over five decades ago and are now regarded to be a settled matter" (Dasgupta 2005, 221-222). Dasgupta suggested that Putnam was promoting the false impression that modern economics is an "ethical desert".

Dasgupta's paper led to a strong response by Putnam and Walsh in Economics and Philosophy (2007a) - to which Dasgupta replied (2007a)and a longer response in the Review of Political Economy (2007b). That ultimately led to a co-edited book (2012), which reprinted their articles together with others by philosophers on their side of the argument. In all these works Putnam and Walsh argue forcefully that Dasgupta has failed to understand Putnam's account of the entanglement of fact and value.

Neither side was persuaded by the other's arguments; despite their exchange in the pages of Economics and Philosophy in 2007, both Dasgupta's and Putnam-Walsh's positions remained unchanged. One can see this because Dasgupta published an adapted version of his original 
2005 paper in The Oxford handbook of philosophy of economics in 2009, under the new title 'Facts and values in modern economics'. Despite the new title the argument remained basically the same as in 2005. The new version made some clarifications in the introductory sections, added a discussion of why Sen's capabilities cannot be seen as primitive ethical notions, and included a short section on estimating poverty. But these changes amplified and clarified his points; they did not change his position. Likewise, Putnam and Walsh did not change their position when revisiting the debate in The end of value-free economics (2012) by reprinting their original contributions (2007a; 2007b, 2009). Given the lapse of time, both sides clearly had the chance to amend their published positions if they wanted to. They chose not to. By examining the debate this paper attempts to clarify the issues in dispute and facilitate communication between philosophers such as Putnam and economists such as Dasgupta.

The paper is organized as follows. In Section 1 we review the origins of the debate between Putnam and Dasgupta. In Section 2 we identify two different issues in relation to the debate-the concept of value and the methodology of economics-and argue that these two issues need to be treated separately. We examine the first issue in Section 3 by placing the Putnam-Dasgupta debate in the context of more recent debate about the role of facts and values in the philosophy of science and the philosophy of economics. We examine the second issue in Sections 4 and 5, arguing that the methodology of economics advocated by Dasgupta does indeed belong to a broad classical tradition as Putnam suggested, but to a Mill-Keynes tradition rather than to the Smithian approach presumed by Putnam and Walsh. In Section 6 we conclude by arguing that seeing Dasgupta as a follower of the Mill-Keynes tradition makes it easier to see precisely where Putnam and Dasgupta disagree. Both are convincing within their own context, but outside of that context there is ambiguity and a resulting lack of communication.

\section{INTELLECTUAL BACKGROUND TO THE PUTNAM-DASGUPTA DEBATE}

To understand the Putnam Dasgupta debate, it is useful to review its origins. In a series of works since the 1980s Putnam has argued against the idea that there is a sharp metaphysical dichotomy between facts and values, and that facts and values are entangled in scientific knowledge (1981; 1990; 1993; 2002; 2003). The main target of Putnam's discussion is logical positivism, which holds that ethical values cannot be legitimate 
subject-matter of science because they are cognitively meaningless. Putnam's fact-value entanglement arguments are applicable to all sciences, but economics has been of particular interest to him because he believes that logical positivism strongly affected the development of economics in the 1930s, and that its influence still lingers in economics today.

According to Putnam, the logical-positivist movement, combined with several other intellectual currents of the time, shaped economists' idea of economics as a scientific discipline in the twentieth century. Among the results of these influences, Putnam argued, was Lionel Robbins's position requiring a clear-cut distinction between economics and ethics, with ethical judgments having no place in the science of economics (Putnam 2002, 53-54). ${ }^{1}$ In Putnam's view, the exclusion of ethics has impoverished economics since then. In particular, the factvalue dichotomy has impoverished the ability of welfare economics to evaluate economic well-being.

Putnam argues that just as economics was embedding a positivist methodology into its vision of itself, philosophy was moving away from logical positivism. As early as 1951 Willard Van Orman Quine launched an attack on the analytic-synthetic dichotomy which, in Putnam's view, eventually collapsed the fact-value dichotomy that lay at the foundation of the logical-positivist approach. In his works Putnam has extended Quine's insights and reinforced the argument against the fact-value dichotomy by exploring the phenomena that he has called the entanglement of fact and value.

The core of Putnam's idea of the entanglement of fact and value is that "the very vocabulary in which we describe human facts [...] frequently fails to be factorable into separate and distinct 'factual' and 'evaluative' components" (Putnam and Walsh 2007b, 185). One of Putnam's own examples can help us understand better what Putnam means by this. According to Putnam, when we say a sentence like 'He is a cruel person', we do not simply 'describe' the person, but also 'evaluate' the person (Putnam 2002, 34-35). It is Putnam's view that when we describe a fact we almost inevitably make an evaluation or

\footnotetext{
1 While Putman follows the standard way of interpreting Robbins, there is an alternative interpretation that sees Robbins's contribution differently (see Colander 2009). In this alternative view, instead of wanting to keep ethical values out of economics, what Robbins actually wanted to do was to reduce some of the most blatant blending of value judgments and supposedly scientific policy conclusions. We do not discuss such points extensively here since they involve history of thought issues rather than philosophical issues.
} 
value judgment as well. Since making a factual judgment almost inevitably involves value judgments, description and valuation are interdependent and entangled. Note that what Putnam argues against is not the practical distinction between facts and values but the metaphysical dichotomy or dualism of fact and value (2002, 9-10). The former still considers that fact and value are not the same. Putnam refutes the dichotomy on the ground that the factual and evaluative components in the vocabulary we use are often simultaneously present. While the "cruelty" case may overstate the point, since scientific technical language is generally structured to avoid such obvious entanglements, we fully agree that if one digs deep enough, all descriptive language, and hence all language in science is inevitably value-laden. That is what might be called a base-line metaphysical entanglement that cannot be avoided. But, as a practical matter, one might still want to call a primarily logical proposition, for example, 'Given a utility function with appropriate assumptions, a derived demand curve will be downward sloping', a fact to be distinguished from a relatively more value laden proposition such as, 'Society will be better off if income is redistributed in some fashion'.

One of Putnam's goals is to enrich modern economics by getting economists to recognize not only the negative critique of the fact-value dichotomy but also the positive opportunities of the entanglement of facts and values. Entanglement demonstrates the legitimacy-indeed necessity-of ethical judgments in economic analysis. A major example cited by Putnam of how this opportunity can be taken up by economists is Amartya Sen's capability approach to studying economic well-being.

Several of Dasgupta's works can be seen as practical demonstrations of Putnam's position. His 1993 book An inquiry into well-being and destitution, among many other works, shows how economists can and should integrate ethical concerns into their research, and even cites Putnam's work as a justification for this approach. Thus it probably came as some surprise to Putnam that Dasgupta's 2005 article advanced a quite different interpretation of what economists, including Dasgupta himself, were doing. In the resulting exchange both sides seemed to be talking past each other.

\section{THE ENTANGLEMENT OF FACT AND VALUE: THE DISAGREEMENT}

In a reply jointly written with Walsh, Putnam argues that Dasgupta completely misread his position on the entanglement of facts, theories, 
and values (Putnam and Walsh 2007a). In response, Dasgupta insists that he understood entanglement perfectly and had no quarrel with it (Dasgupta 2007a).

In examining why they disagree, let us start with an example where their disagreement is evident. In closing his paper, Dasgupta (2005) offers two quotations-from Reutlinger and Pellekaan (1986) and from the World Bank's 1986 World development report-to support his central claim that economists have shared ethical values, but differ in their reading of the facts. The same quotations are also used by Putnam and Walsh as evidence that Dasgupta had failed to understand what they meant by the entanglement (Putnam and Walsh 2007b, 185-187). ${ }^{2}$ These two quotations are as follows:

[L]ong run economic growth is often slowed by widespread chronic food insecurity. People who lack energy are ill-equipped to take advantage of opportunities for increasing their productivity and output. That is why policymakers in some countries may want to consider interventions that speed up food security for the groups worst affected without waiting for the general effect of long-run growth (Reutlinger and Pellekaan 1986, 6).

The best policies for alleviating malnutrition and poverty are those which increase growth and the competitiveness of the economy, for a growing and competitive economy facilitates a more even distribution of human capital and other assets and ensures higher incomes for the poor. Progress in the battle against malnutrition and poverty can be sustained if, and only if, there is satisfactory economic growth (World Bank 1986, 7).

In this case, in saying that economists have shared values, Dasgupta means that the ethical desirability of eliminating destitution is presumed by both sets of authors. He sees the difference in policy recommendations as disagreements concerning the most effective means of eliminating destitution that follow from the two parties' differing views of the central causal mechanisms. In contrast, in arguing that the disagreement between the two sets of authors is of an entangled character, Putnam and Walsh mean that the apparent divergence in views regarding the most effective means is actually the result of the authors' different values. In their view, the authors of the World development report do not truly share the value of eliminating

\footnotetext{
${ }^{2}$ In fact, the two quotations also appeared in the first chapter of Dasgupta's 1993 book. It is clear that Dasgupta's standpoint did not change over time.
} 
destitution with Reutlinger and Pellekaan: the apparent value agreement is just a disguise for their real unspeakable values (Putnam and Walsh 2007b, 186).

Our claim is that the arguments of both sides can be seen as convincing within their own context while simultaneously being seen as incomplete from the perspective of the other side. Dasgupta is clearly aware that ethical values are often the motivation for economic studies, and hence he agrees that that economics is not value-free. Moreover, he believes, rightly or wrongly, that the ethical values which motivate most economic research are widely shared by economists. There is little doubt that Dasgupta recognizes the entanglement of fact and value at the initial stage of a research project, but he seems to believe that at the later stages of the research, the evaluation of facts will not be entangled with ethical values, though he does not deny that other types of values may be involved (Dasgupta 2007a, 471). Putnam disagrees with him on the latter point. For Putnam, it is impossible to make a statement about facts without making an ethical value judgment. He believes that on this point Dasgupta has failed to comprehend the true meaning of his analysis of entanglement and its implications.

Putnam and Walsh argue that the values held by Reutlinger and Pellekaan are different from those of the World Bank, and that this difference in values is at the root of their different reading of the facts. Their sharp critique points out the problem that economists may use so-called 'scientific' theory as cover for ideological beliefs. But can this argument alone defeat Dasgupta's position that economists, even when sharing ends, would still have different views regarding which means would be most effective for achieving them due to their different readings of the facts? And isn't it possible that economists do genuinely agree about some ends, yet still disagree about means due to different understandings of the relevant facts, such as causal mechanisms?

We believe that it is indeed possible, and that as a practical matter good economists, such as Dasgupta, focus their applied work on an analysis of "facts", while recognizing that on a deeper metaphysical level facts and values are intertwined. In developing that applied empirical work, for example in identifying and studying specific causal mechanisms, they will come to different judgments about the facts and their real world significance, but those differing judgments do not mean that they differ about the ultimate goal. 


\section{VALUE-FREE ECONOMICS?}

The debate between Putnam and Dasgupta is just part of a more general debate between philosophers of science. Insight can be gained into their debate by considering that broader philosophical debate, specifically the work of Andrea Scarantino (2009), who divided the relationship between science and values into three types: the 'naïve positivist view', the 'separatist view', and the 'non-separatist view'. The naïve positivist view is that values should not play any role at any stage of the activities of scientific economists and that, if they do, economists have violated the methodological conventions that make economics a science. Neither Putnam nor Dasgupta holds those views. Where they differ is that Dasgupta is more of a separatist, and Putnam is more of a nonseparatist.

Following Scarantino (2009), in order to distinguish the separatist and non-separatist views we need to distinguish both between epistemic values and non-epistemic values, and between internal activities and bordering activities. The epistemic/non-epistemic distinction is similar to the distinction made by Mark Blaug between 'methodological values' and 'normative values' (Blaug 1992, 114; 1998, 372). The term 'epistemic value' is used by philosophers of science to refer to those values which govern the meaning and formulation of scientific knowledge. For instance, accuracy, consistency, and simplicity. In contrast, 'non-epistemic value' is used to refer to all other values that may be involved, i.e., values which are not instrumental to the establishment of scientific knowledge. Ethical, political, and sociocultural values belong to this category. Internal activities are the core activities that economists do-the research that determines what will be considered economic facts (Scarantino 2009, 465-466). They relate to what philosophers call the context of justification. Bordering activities refer to the selection of which economic problems to investigate, or what philosophers call the context of discovery, and to the use made of economic knowledge once acquired.

According to Scarantino, the non-separatist view holds that "both epistemic and non-epistemic values have a legitimate role to play in the 'internal activities' of scientific economists" (2009, 466). ${ }^{3}$ Putnam can thus be seen as a non-separatist. For him, it is impossible to exclude

\footnotetext{
${ }^{3}$ Other scholars who hold this view include Phyllis Rooney (1992), Peter Machamer and Heather Douglas (see Machamer and Douglas 1999; Douglas 2007), and Helen Longino (1990).
} 
values-both epistemic and non-epistemic-from either the internal or the bordering activities of economists.

The separatist view lies in between the naïve positivist view and the non-separatist view. While the naïve positivist view represents the ideal of science as free from all values, the separatist view represents the ideal of science as free only from non-epistemic values because it recognizes the inevitability of epistemic values in scientific activities. Moreover, as Scarantino points out, it is compatible with separatism to see the bordering activities of scientific economics as laden with non-epistemic values. But the legitimate influence of non-epistemic values is restricted to the prior and posterior stages of the pursuit of economic knowledge, such as choosing socially significant problems to work on and interpreting the policy relevance of results.

Using Scarantino's classification, the disagreement between Putnam and Dasgupta about Dasgupta's position can be better understood. Putnam sees Dasgupta as a naïve positivist whereas the view Dasgupta actually holds seems closer to separatism. This understanding of their debate by no means allows us to resolve the ongoing disagreement between non-separatism and separatism. Nevertheless, the removal of an apparent misunderstanding can be a first step to more effective communication between them, since they would at least be in agreement about what it is they are disagreeing about.

Putnam is fully aware of the distinction between epistemic and non-epistemic values. But he does not put much weight on it, because he considers that both types of values are ultimately inseparable (Putnam 2002, 31-33). Indeed, it is likely that non-epistemic values would indirectly influence economists' research by influencing how epistemic values are taken up. But the distinction does help us to clarify that whether economics is value-free is not the key point in the debate between Putnam and Dasgupta: both believe that economists' bordering activities are laden with non-epistemic values and that their internal activities are laden with epistemic values. The real disagreement between them is about whether any part of economic analysis can be free from ethical value judgments, or, more precisely, whether economists can avoid making ethical judgments in their internal activities. In our view, Putnam does not respond to this question adequately in his reply to Dasgupta, even if his non-separatist view is the right one. 
Several outstanding economists and economic methodologists have advocated a careful study of the impact of values on the scientific activities of economists. For instance, back in the 1930s Gunnar Myrdal (1953 [1930]) argued that economists' personal traits, disciplinary traditions, and the interests and prejudices of the society they lived in would inevitably influence their research through influencing the approach they chose, their explanatory models and theories, the concepts they used, and the procedures they followed in making observations and drawing inferences. In 1973 Myrdal reiterated his argument, emphasizing the importance of studying the sociology and psychology of economists (Myrdal 1973). However, until recently the exploration of these fields remained a "neglected agenda" (see Backhouse 2005). How the formation of economic knowledge is influenced by non-epistemic values acting through epistemic values is indeed an important question. But in addition to pursuing a full account of such issues, there might be some other ways in which economists can improve the quality of economic studies. We argue that Dasgupta believes so and that this is the key message of his 2005 article.

\section{DASGUPTA'S MISSED MESSAGE ABOUT ECONOMIC METHODOLOGY}

The title of Dasgupta's 2005 paper 'What do economists analyze and why: values or facts?' implies the dichotomy of facts and values rather than their entanglement, as Putnam and Walsh commented. It reinforces the puzzle of why Dasgupta would insist that economists study facts not values if he accepts the entanglement of facts and ethical values, at least to some degree. We believe that Dasgupta had an important message to convey but failed to communicate it clearly, and we suggest that Putnam and Walsh's failure to understand him was partly due to their reading of him as under the influence of the logical-positivist tradition with its demarcation between fact-based science and valuebased ethics. Dasgupta's position cannot actually be understood in this logical-positivist tradition.

For Dasgupta, the main challenge for policy analysis in the economics profession at present is not the lack of ethical foundations. The much more pressing issue for economists is to improve their understanding of the factual side of social problems. In our view, Dasgupta's claim that economists share many ethical values is an overstatement, but one that can be justified as a reasonable simplification that explains and justifies why economists try to 
structure their debates so as to focus on issues where their ethical differences are not in play. The simplification is a useful idealization because it allows Dasgupta to focus on the more important claim that refining our understanding of the factual aspects of a social phenomenon can benefit the policy debate regardless of what one's ethical views are. In our view, this key point in Dasgupta's argument did not receive enough attention from Putnam and Walsh. As an economist, and perhaps especially as a development economist, Dasgupta's main concern is with how to refine our understanding of facts for policy analysis. That is a question about the pragmatic methodology that economists should use. Dasgupta's aim is mainly practical, not theoretical or philosophical. He does not so much downplay the significance of ethics as play up the significance of operational solutions that improve policy analysis. As he put it bluntly, "I am a practicing economist, not a philosopher" (Dasgupta 2007a, 370).

Dasgupta is not alone. The goal of improving the reading of facts for practical purposes has a long history in economics. Pursuing this goal does not really distinguish him from other contemporary economists. What makes Dasgupta unusual is his practice of economics, which, as recognized by Putnam and Walsh, distances him from mainstream neo-Walrasian theory and puts him more in line with classical economic theory (Putnam and Walsh 2007b, 195). We also see Dasgupta's approach as in line with the classical tradition. But unlike Putnam, who associated Dasgupta with Adam Smith, we argue that Dasgupta's approach to economic policy analysis is better placed in the Mill-Keynes tradition. Looking through this lens, what Dasgupta is doing is consistent with what he claims he is doing.

\section{DASGUPTA AND THE MILL-KEYNES TRADITION OF METHODOLOGY}

Putnam and Walsh (2007b, 193-195) quoted extensively from Dasgupta's discussion of destitution to demonstrate that Dasgupta's work belonged to the classical tradition. Using the same passages quoted by Putnam and Walsh, we will provide an alternative reading of Dasgupta.

[A]ll the equilibria in the timeless economy are Pareto-efficient [...] This means, among other things, that there are no policies open to the government for alleviating the extent of undernourishment other than those that amount to consumption or asset transfers. A common wisdom is that such policies impede the growth of an economy's productive capacity because of their detrimental effect 
on saving and investment, incentives, and so forth. But this is only one side of the picture. Our model will stress the other side, which is that a transfer from the well-off to the undernourished can enhance output via the increased productivity of the impoverished (Results 7 and 8). We don't know in advance which is the greater effect, but to ignore the latter yields biased estimates of the effects of redistributive policies. [...]

By developing the economics of malnutrition, I will offer a final justification for the thesis that it is the singular responsibility of the State to be an active participant in the allocation mechanism guiding the production and distribution of positive and negative freedoms. This justification is built on the idea that in a poor economy markets on their own are incapable of empowering all people with the opportunity to convert their potential labour power into actual labour power. As a resource allocation mechanism, markets on their own simply aren't effective. The theory I will develop below also shows how a group of similar poor people can become fragmented over time into distinct classes, facing widely different opportunities. Risk and uncertainty will play no role in this. It is a pristine theory of class formation (Dasgupta 1993, 476-477).

Putnam and Walsh used these passages as evidence of the factvalue entanglement in Dasgupta's work and the concordance between Dasgupta's and Smith's economic writings. But reading Dasgupta through the Mill-Keynes lens gives us what seems a better view of his true intentions. We suggest the similarities of Dasgupta's approach with the Mill-Keynes tradition can be identified from the following two aspects.

a) The knowledge of 'what ought to be' is distinct from, but based on, the knowledge of 'what is'.

Dasgupta's work suggests that he would accept the science-art distinction proposed by John Stuart Mill. On the one hand, science and art are distinct (Mill 1967 [1844], 312). Science, which concerns the knowledge of 'what is', is different in nature from art, which concerns the knowledge of 'what ought to be'. On the other hand, science and art are closely interrelated. Art assigns ends to science; science informs art of the means available for achieving those ends; based on the knowledge provided by science, art decides what ought to be done to achieve the ends (Mill 1974 [1872], 944-945). Note that the science-art distinction is not equivalent to the fact-value dichotomy. A key difference between the 
two is that while the latter implies that science deals with facts and art deals with values, the former does not.

From the second passage cited above, we can see how Dasgupta intends to base his normative judgment on the knowledge of facts provided by science. The statement that "it is the singular responsibility of the State to be an active participant in the allocation mechanism guiding the production and distribution of positive and negative freedoms" is a normative one. It is clear in Dasgupta's writing that this normative judgment "is built on" the idea that "in a poor economy markets on their own are incapable of empowering all people with the opportunity to convert their potential labour power into actual labour power", which is a reading of fact derived from his scientific economic analysis of malnutrition (Dasgupta 1993, 477). Dasgupta would not deny that his claim that markets are incapable of empowering all people might involve a value judgment, but for him the statement is a positive statement, not a normative one. The statement does not indicate what ought to be done. It alone cannot tell us why the State rather than non-governmental organizations should be the remedy for the failure of markets. It does not even suggest that leaving the markets alone should not be an option, unless we already consider it desirable to try to empower all people to convert their potential labour power into actual labour power and this aim is not trumped by other aims.

b) It is necessary to adopt an interdisciplinary approach to reading facts to remedy the limitations of mainstream models relating to their unrealistic assumptions.

Despite being critical of mainstream economic models, Dasgupta does not deny their contribution. He has issues with them because he believes they present an unrealistic view of the world-because their construction neglects crucial facts, such as basic needs and physiological phenomena-and hence they are unable to provide an accurate reading of economic phenomena. For Dasgupta, the mainstream models can be a poor guide to the causal mechanisms involved because of inappropriate assumptions and construction. The ethical values held by economists might be the cause of the problem, but not necessarily. In his 2005 article, Dasgupta shows that as a practicing economist he aims to deal with those cases in which ethical values are not the cause of economists' mistaken reading of causality. 
In view of the limitations of the standard models, Dasgupta includes scientific knowledge from outside economics in his analysis of policy. In his research, the knowledge provided by disciplines such as physiology, the science of nutrition, ecology, and so on, plays an important role in understanding the factual side of social phenomena. ${ }^{4}$

At the very beginning of chapter 16 of his 1993 book, Dasgupta points out that the standard theory of resource allocation fails to take into account the fact that meeting physiological maintenance requirements is a precondition of labour power. The term 'economic disfranchisement' is used by Dasgupta to point out the illusion, suggested by the standard theory, that every labourer is on an equal footing in terms of converting potential labour power into real labour power in the labour market. He therefore attempted to construct a theory that took human physiology into account.

It is true that the ethical values held by Dasgupta may have contributed to his interest in the phenomenon of economic disfranchisement and redistributive policies. Yet it is also true that although concluding that "models that are dissonant with physiological truths are hopelessly incomplete" $(1993,475)$, Dasgupta does not attack the standard theory from an ethical point of view, but from a factual point of view. From the first passage cited above, we can see that Dasgupta intends to disprove the "common wisdom" by showing that the outcomes derived from the standard model will not come about if the positive effects on productivity of a transfer from the well-off to the undernourished are greater than its negative effects on saving and investment. The approach he took to refute the standard theory is very much 'scientific' in Mill's sense, rather than 'ethical' or 'normative'.

According to Mill, social science is a deductive enterprise, but one which follows the model of the physical sciences, rather than that of geometry. Social science, he wrote,

infers the law of each effect from the laws of causation on which that effect depends; not, however, from the law merely of one cause, as in the geometrical method; but by considering all the causes which conjunctly influence the effect, and compounding their laws with one another (Mill 1974 [1872], 895).

\footnotetext{
${ }^{4}$ See, for instance, Dasgupta 1990; 1997; 2003; 2007b; 2008; Dasgupta and Ray 1987; Dasgupta and Mäler 2000.
} 
In Mill's view, the complexity of social phenomena does not arise from the number of the laws, but "from the extraordinary number and variety of the data or elements-of the agents which, in obedience to that small number of laws, co-operate towards the effect" (Mill 1974 [1872], 895).

Dasgupta's approach to asset transfer policies is a good example of Mill's deductive method. Dasgupta identifies two main effects of a transfer: decreasing savings and investment on the one hand while increasing the productivity of the impoverished on the other hand. These two tendencies can be seen as co-existent intermediate mechanisms which will have different effects on economic growth. According to the physical 'deductive method', the final result of the transfer policy should be estimated by summing up the individual effects of the co-existent intermediate causes. In contrast, the approach adopted by the standard model is equivalent to the 'geometrical method' because it does not admit the modification of the presumed psychological law (the behaviour of saving and investing will be negatively affected by the transfer) by another law (the improvement in nutrition will increase productivity).

It is worth noting that Mill does not pretend that it is possible to calculate the aggregate result of many co-existent causes with complete precision. In his view, it is beyond human faculties to take into account all the causes which happen to exist in one case (Mill 1974 [1872], 898). But, as a practical science, if economics can provide us with knowledge of tendencies, it gives us a considerable power to "surround [our] society with the greatest possible number of circumstances of which the tendencies are beneficial, and to remove or counteract, as far as practicable, those of which the tendencies are injurious" (Mill 1974 [1872], 898).

From the above discussion, we can see that the scientific aspirations of Dasgupta's economic writings are clearly in line with the approach explicitly stipulated by Mill. This scientific dimension is absent from Smith's work. Indeed, Mill's proposal of the science-art distinction specifically took Smith as a target. In Mill's view, the title and arrangement of Smith's book An inquiry into the nature and causes of the wealth of nations, despite being suitable for the purpose of his work, had caused a general misunderstanding of the nature of economics as a science. Smith's approach tended to mix up what makes a nation rich (what is) with what a nation ought to do to increase its wealth (what 
ought to be done). For Mill, the latter is not an appropriate subject for scientific economics; it should be the subject of political economy as art (Mill 1967 [1844], 312). Moreover, according to Smith the object of political economy is firstly to enable the country's people to provide sufficient necessaries and conveniences of life for themselves and secondarily to supply the state with a revenue sufficient for the public service (Smith 1976 [1776], book 5, Introduction). For Mill, the desirability of these objects is determined by art, not by science (Mill 1967 [1844], 312).

Dasgupta is not the only economist whom Putnam and Walsh have held up as a paradigm of Smithian methodology, and not the only one who turns out not to fit that model quite as well as they supposed. Putnam and Walsh have also suggested that Sen's work, and especially his capability approach, is in the Smithian tradition (Putnam 2002, 2003; Putnam and Walsh, 2007b). In terms of Sen's methodology, we do not see it that way-Smith blended normative and positive analysis without separating normative and positive economics in any logical way. Sen does the opposite; he carefully specifies what in his analysis is normative and what is positive, and explains why his normative analysis is much more consistent with most people's normative views than are the implicit normative judgments in standard analysis. This, in our view, puts him in the Mill-Keynes methodological tradition, which evolved from Smith's partly by criticizing Smith for his lack of clarity about the difference between what economics studies and what the ends of economics and economic policy ought to be.

In the first chapter of his book On ethics and economics (1987), Sen identifies two origins for economics in ethics and engineering. Sen groups Smith and Mill together in the ethics-related tradition, which is correct in the sense that both Smith and Mill see economics as a branch of moral philosophy (i.e., the ultimate end of economic knowledge is to make life better, and hence ultimately economics cannot be independent from ethics). But we would add an extra distinction to Sen's classification that allows us to distinguish Smith and Mill in terms of their methodology. Whereas Smith blended his normative and positive analysis together, Mill carefully attempted to distinguish art from science. Thus, like Putnam and Walsh, we see Sen as following Smith's (and Mill's) ethical tradition-in the sense of seeing economics as a branch of moral philosophy. But unlike them we see Sen's methodology as deriving from the more sophisticated Mill-Keynes tradition rather 
than Smith's. This is what we mean by saying that Sen belongs to the Mill-Keynes approach, not the Smithian approach.

It is intriguing to note that enriching the nation, the major goal of Smith's political economy, has been implicitly taken over by many modern economists as a value-neutral goal, while equitable distribution, which is less directly addressed by Smith, is considered as value-laden and hence as an illegitimate subject for economics. Mill's distinction between science and art could in effect support Putnam's intention of revealing the biased attitude of some economists towards different ethical values that leads to biased readings of facts.

Dasgupta rarely if ever refers to Mill in his work. However, it is not entirely surprising to find similarities between their methods of doing economics. Daniel Hausman once commented that "[t]he temper and character of modern economics still embodies the Millian vision of the discipline as a separate science" (Hausman 1992, 225). Modern economics may not have developed in quite the way Mill had hoped, but it is fair to say that his analysis of the nature and methodology of economics was indirectly and partially inherited by contemporary economists through the influence of John Neville Keynes and Robbins.

In The scope and method of political economy (1917 [1890]), J. N. Keynes took up Mill's distinction between positive science and normative art and further developed it into a tripartite division of economics in accordance with his classification of knowledge According to this classification, a positive science is a body of systematized knowledge concerning what is; normative or regulative science is a body of systematized knowledge relating to the criteria of what ought to be; and an art is a system of rules for the attainment of a given end. Each has its own distinct objectives: for a positive science the objective is to establish uniformities; for a normative science it is to determine ideals; for an art it is to formulate precepts. Accordingly, investigations into economic uniformities, economic ideals, and economic precepts can be categorised respectively as the positive science of political economy, the ethics of political economy, and the art of political economy (see 1917 [1890], 31-36). ${ }^{5}$

In our view, the Millian approach did not end with J. N. Keynes. In particular, we have argued elsewhere (Colander 2009) that Robbins is best interpreted as working within this tradition, and that that sheds

\footnotetext{
${ }^{5}$ For a detailed discussion of Keynes's tripartite division of economics, see Colander 1992.
} 
a quite different light on his message. Specifically, we argue that Robbins (1945 [1932]) advocated not only the importance of separating positive economics from ethics but also a separate, non-scientific branch of economics to deal with issues of values. Robbins noted that the majority of classical economists used the term political economy to cover "a mélange of objective analysis and applications involving value judgments" (1976, 1; 1981, 7). In his 1981 Ely Lecture and in the introduction to his 1976 book Political economy, past and present, Robbins suggested that the use of the term 'political economy' should be revived, to maintain a space in economics where ethical values play a central role (1976, 2-3; 1981, 7-8). ${ }^{6}$ According to Robbins, this political economy is not part of economic science, but it is an integral part of economic studies.

Mill's call for economics as a science separate from art has been largely realized in the economics profession over the past 150 years, but the line of descent from Mill through Keynes and Robbins to today took various turns. Each inflexion caused some changes to the direction of the development of economics, and the final outcome is very different from what Mill would have expected. We do not deny the problems of modern economics that emerged during its formation as a separate discipline. But, with a correct understanding of the Mill-Keynes tradition of methodology, and particularly by recovering the integral role of art in economic studies, the economics profession could do a much better job than it does now to highlight the way values are integrated into economic analysis. ${ }^{7}$

Specifically, we believe that when Dasgupta's arguments are interpreted through the Mill-Keynes lens, rather than a Smithian one, his arguments make much more sense philosophically. They are not deep philosophical arguments but pragmatic arguments about how to move forward in tentatively separating positive truths from normative rules, even while accepting that on a deep level they may not be fully separable. Instead of letting fact-value entanglement lead one to an

\footnotetext{
${ }^{6}$ Robbins uses the term in a narrower sense than Smith: Robbins uses the term to designate only the prescriptive part of economic investigation, whereas Smith's political economy concerned both what we have been calling positive science and normative art.

7 We have discussed elsewhere how the economics profession can improve by reintroducing the Mill-Keynes methodological tradition (see Colander 1992, 2001, 2013; Su 2012). It involves distinguishing separate methodological approaches for applied policy economics and for the pure science of economics, along the lines suggested by J. N. Keynes.
} 
impasse, one distinguishes those factual judgments and normative judgments that are most separable, accepts that others are not, and gets on with one's analysis.

We are not especially concerned with whether Dasgupta is actually a follower of either Smith or Mill. Our argument is that seeing Dasgupta within the Mill-Keynes tradition helps clarify his methodology. The MillKeynes interpretation allows us to understand how Dasgupta considers himself able to integrate ethical considerations into his economic policy analysis without sacrificing the scientific character and objectivity of his economic analysis. In the Mill-Keynes methodological tradition, the scientific branch of economic studies is separated from applied economic policy analysis. The separation is meant to enhance the quality of the latter by improving the understanding of economic phenomena through adopting appropriate scientific methods. Putnam may disagree with the Mill-Keynes methodology, but we believe his criticisms would be better understood by Dasgupta, and other economists, if they took explicit account of the pragmatic art-science foundations of his methodology, and did not reduce them immediately to the fact-value dichotomy associated with the logical-positivist tradition, and which the Mill-Keynes economic tradition did not embrace.

\section{CONCLUSIONS}

The debate between Putnam and Dasgupta was perceived by Putnam to be about whether economics is value-free or not, as indicated by the title of his recent book with Walsh about their side of the debate, The end of value-free economics. We have suggested in this paper that this was a misperception. The fact-value divide is problematic, but it is not the key to the Putnam-Dasgupta debate. We have argued that Dasgupta was mistakenly understood by Putnam and Walsh as holding a naïve positivist view, which insists on a dichotomy between fact-based science and value-based ethics and argues that economics should be free from all sorts of values. In our view, the confrontation between Putnam and Dasgupta is actually between a non-separatist view and a separatist view. More specifically, the disagreement between them is about whether it is possible for economists to avoid making ethical value judgments when they try to explain observed economic phenomena in an objective factual way. 
The philosophy of science debate between the non-separatist view and the separatist view is on-going. The implications of these two views for scientific activities require more investigation. In particular, if ethical value judgments cannot be avoided even in internal scientific activities - as the non-separatist view claims-then it is important for economists to understand how this entanglement occurs in order to know how to minimize the resulting biases in their research, as much as one can. However, real-world economic problems are pressing and cannot wait for solutions until we have a satisfactory answer to these profound questions. Moreover, even if it is true that economists' reading of facts is inevitably influenced by their personal values, it is not necessarily the case that their different readings of the facts can be solely explained by differences in their ethical values. For these reasons, the value of Dasgupta's call for refining the reading of facts should be acknowledged, and the Mill-Keynes tradition rediscovered.

\section{REFERENCES}

Backhouse, Roger. 2005. Economists, values and ideology: a neglected agenda. Revue de Philosophie Économique, 11: 49-73.

Blaug, Mark. 1992 [1980]. The methodology of economics: or, how economists explain. Cambridge: Cambridge University Press.

Blaug, Mark. 1998. The positive-normative distinction. In The handbook of economic methodology, eds. John Davis, D. Wade Hands, and Uskali Mäki. Cheltenham (UK): Edward Elgar, 370-374.

Colander, David. 1992. The lost art of economics. The Journal of Economic Perspectives, 6 (3): 191-198.

Colander, David. 2001. The lost art of economics: economics and the economics profession. Cheltenham (UK): Edward Elgar.

Colander, David. 2009. What was "it" that Robbins was defining? Journal of the History of Economic Thought, 31 (4): 437-448.

Colander, David. 2013. The systemic failure of economic methodologists. Journal of Economic Methodology, 20 (1): 56-68.

Dasgupta, Partha. 1990. Well-being and the extent of its realization in poor countries. Economic Journal, 100 (400): 1-32.

Dasgupta, Partha. 1993. An inquiry into well-being and destitution. Oxford: Oxford University Press.

Dasgupta, Partha. 1997. Nutritional status, the capacity for work and poverty traps. Journal of Econometrics, 77 (1): 5-37.

Dasgupta, Partha. 2003. Population, poverty, and the natural environment. In Handbook of environmental and resource economics: environmental degradation and institutional responses, eds. Karl-Göran Mäler, and Jeffrey R. Vincent. North Holland: Elsevier, 191-248. 
Dasgupta, Partha. 2005. What do economists analyze and why: values or facts? Economics and Philosophy, 21 (2): 221-278.

Dasgupta, Partha. 2007a. Reply to Putnam and Walsh. Economics and Philosophy, 23 (3): 365-372.

Dasgupta, Partha. 2007b. Nature and the economy. Journal of Applied Ecology, 44 (3): 475-487.

Dasgupta, Partha. 2008. Nature in economics. Environment Resource Economics, 39 (1): 1-7.

Dasgupta, Partha. 2009. Facts and values in modern economics. In The Oxford handbook of philosophy of economics, eds. Harold Kincaid, and Don Ross. Oxford: Oxford University Press, 580-640.

Dasgupta, Partha, and Karl-Göran Mäler. 2000. Net national product, wealth, and social well-being. Environment and Development Economics, 5 (1): 69-93.

Dasgupta, Partha, and Debraj Ray. 1987. Inequality as a determinant of malnutrition and unemployment: policy. The Economic Journal, 97 (385): 177-188.

Douglas, Heather. 2007. Rejecting the ideal of value-free science. In Value-free science?: ideas and illusions, eds. Harold Kincaid, John Dupré, and Alison Wylie. Oxford: Oxford University Press, 143-163.

Hausman, Daniel. 1992. The inexact and separate science of economics. Cambridge: Cambridge University Press.

Keynes, John Neville. 1917 [1890]. The scope and method of political economy. London: Macmillan.

Longino, Helen E. 1990. Science as social knowledge. Princeton: Princeton University Press.

Machamer, Peter, and Heather Douglas. 1999. Cognitive and social values. Science and Education, 8 (1): 45-54.

Mill, John Stuart. 1967 [1844]. On the definition of political economy; and on the method of investigation proper to it. In Collected works of John Stuart Mill, vol. IV, ed. J. M. Robson. Toronto: Toronto University Press, 309-339.

Mill, John Stuart. 1974 [1872]. A system of logic, ratiocinative and inductive. In Collected works of John Stuart Mill, vol. VIII, ed. J. M. Robson. Toronto: Toronto University Press, 833-952.

Myrdal, Gunnar. 1953 [1930]. The political element in the development of economic theory. London: Rutledge and Kegan Paul.

Myrdal, Gunnar. 1973. The need for a sociology and psychology of social science and scientists. In Against the stream: critical essays on economics. New York: Pantheon Books, 52-64.

Putnam, Hilary. 1981. Reason, truth, and history. Cambridge: Cambridge University Press.

Putnam, Hilary. 1989. Objectivity and the science/ethics distinction. WIDER Working Paper 70. World Institute for Development Economics Research, Helsinki, FI.

Putnam, Hilary. 1990. Realism with a human face. Cambridge (MA): Harvard University Press.

Putnam, Hilary. 1993. Objectivity and the science-ethics distinction. In The quality of life, eds. Martha Nussbaum, and Amartya Sen. Oxford: Clarendon Press, 143-157.

Putnam, Hilary. 2002. The collapse of the fact/value dichotomy. Cambridge (MA): Harvard University Press. 
Putnam, Hilary. 2003. For ethics and economics without the dichotomies. Review of Political Economy, 15 (3): 395-412.

Putnam, Hilary and Vivian Walsh. 2007a. A response to Dasgupta. Economics and Philosophy, 23 (3): 359-364.

Putnam, Hilary, and Vivian Walsh. 2007b. Facts, theories, values and destitution in the works of Sir Partha Dasgupta. Review of Political Economy, 19 (2): 181-202.

Putnam, Hilary, and Vivian Walsh. 2009. Entanglement throughout economic science: the end of a separate welfare economics. Review of Political Economy, 21 (2): 291-297.

Putnam, Hilary, and Vivian Walsh. 2012. The end of value-free economics. London: Routledge.

Quine, Willard Van Orman. 1951. Main trends in recent philosophy: two dogmas of empiricism. Philosophical Review, 60 (1): 20-43.

Reutlinger, Shlomo, and Jack van Hoist Pellekaan. 1986. Poverty and hunger: issues and options for food security in developing countries. Washington: World Bank.

Robbins, Lionel. 1945 [1932]. An essay on the nature and significance of economic science. London: Macmillan.

Robbins, Lionel. 1976. Political economy, past and present: a review of leading theories of economic policy. London: Macmillan.

Robbins, Lionel. 1981. Economics and political economy. The American Economic Review, 71 (2): 1-10

Rooney, Phyllis. 1992. On value in science: is the epistemic/non-epistemic distinction useful? Proceedings of the Biennial Meeting of the Philosophy of Science Association, 1: 13-22.

Scarantino, Andrea. 2009. On the role of values in economic science: Robbins and his critics. Journal of the History Economic Thought, 31 (4): 449-473.

Sen, Amartya. 1987. On ethics and economics. Oxford: Basil Blackwell.

Smith, Adam. 1976 [1776]. An inquiry into the nature and causes of the wealth of nations, ed. Edwin Cannan. Chicago: University of Chicago Press.

$\mathrm{Su}$, Huei-chun. 2012. Beyond the positive-normative dichotomy: some remarks on Colander's lost art of economics. Journal of Economic Methodology, 19 (4): 375-390.

World Bank. 1986. World development report. Oxford: Oxford University Press.

Huei-chun Su is an honorary research associate at the Bentham Project at University College London, UK. She is the author of the book Economic justice and liberty: the social philosophy in John Stuart Mill's utilitarianism (Routledge, 2013). Her research interests include history of economic thought, philosophy of social and economic policies, and moral philosophy.

Contact email: <h.su@ucl.ac.uk>

David Colander is College professor at Middlebury College. He has authored, co-authored, or edited over 40 academic books as well as numerous textbooks, and 150 articles on a wide range of topics. 
His books have been, or are being, translated into a number of different languages, including Chinese, Bulgarian, Polish, Italian, and Spanish. His most recent book (with Roland Kupers) is Complexity and the art of public policy: solving society's problems from the bottom up (Princeton University Press, 2014).

Contact email: <colander@middlebury.edu> 